\title{
PENGEMBANGAN AGROPOLITAN \\ DI PROPINSI RIAU \\ 2005
}

\section{A. PENDAHULUAN}

\section{Latar Belakang}

Konsepsi Pembangunan selama ini dilakukan dengan pendekatan terpusat dengan mendorong percepatan pertumbuhan ekonomi di pusatpusat wilayah perkotaan, dengan harapan pertumbuhan ekonomi di Pusat Pertumbuhan memberikan dampak penetesan kepada daerah di belakangnya (trikle down effect), namun kenyataan yang terjadi Pertumbuhan ekonomi di Pusat-Pusat pertumbuhan yang dirancang, tidak memberikan dampak penetesan ke bawah, justru menimbulkan efek pengurasan sumberdaya dari wilayah sekitarnya (backwash effect).

Pemerintah dengan berbagai cara selalu berupaya memperbaiki konsep pembangunan yang dapat menghasilkan pemerataan pertumbuhan dan kesejahteraan masyarakat, salah satunya adalah yang di gagas oleh Departemen Pertanian melalui Badan Pengembangan SDM Pertanian yaitu melakukan pembangunan pertanian dengan pendekatan Agropolitan.

Konsep pengembangan AGROPOLITAN muncul dari permasalahan adanya ketimpangan pembangunan wilayah antara kota sebagai pusat kegiatan dan pertumbuhan ekonomi dengan perdesaan sebagai pusat kegiatan pertanian yang tertinggal. Proses interaksi kedua wilayah selama ini secara fungsional ada dalam posisi saling memperlemah.

Dalam konteks spasial, proses pembangunan yang terjadi pada kenyataannya telah menimbulkan berbagai permasalahan yang berkaitan dengan tingkat kesejahteraan antar wilayah (desa-kota).

Wilayah KOTA secara umum ditandai dengan kegiatan : Sektor ekonomi dominan berupa industri pengolahan; Perdagangan \& jasa yang kuat; Dihuni oleh sumberdaya manusia yang berkualitas; serta Tingkat pelayanan infrastruktur yang cukup dan lengkap.

Sementara pada sisi lain wilayah PEDESAAN diditandai dengan kegiatan dominan di sektor pertanian dalam arti luas; Dihuni oleh SDM 
dengan tingkat pendidikan yang rendah; Kemiskinan; dan Tingkat pelayanan infrastruktur yang terbatas.

Di Propinsi Riau Pengembangan Agropolitan sampai Tahun 2005 telah dilaksanakan di 3 Kabupaten yaitu Indragiri Hilir, Rokan Hulu dan Kampar. Pengembangan Kawasan Agropolitan tersebut tentunya dilaksanakan dengan memperhatikan potensi Sumberdaya Alam Propinsi Riau dan lapangan usaha utama masyarakat Riau yaitu Sektor Pertanian $(47,90 \%)$, serta untuk mempercepat perkembangan kegiatan Usaha Pertanian yang baru Dalam Bentuk Pembangunan Produksi Pertanian (Budidaya).

Pengembangan konsep Agropolitan ini dilakukan melalui upaya dan pertimbangan dalam rangka menciptakan keterpaduan, tidak saja dalam usaha budidaya (on farm) tetapi juga meliputi pembangunan agribisnis hulu (penyediaan sarana-prasarana pertanian), agribisnis hilir (prosessing dan pemasaran hasil pertanian), serta jasa-jasa pendukungnya (sub-sistem pelayanan jasa).

Dengan demikian titik tolak pembangunan sektor pertanian perlu dilakukan perubahan penekanan dari yang semula lebih banyak bertumpu pada pembangunan produksi (sub-sistem budidaya), kepada pembangunan sistem dan usaha agribisnis dimana seluruh sub-sistem agribisnis (budidaya; sarana prasarana produksi; pengolahan hasil; pemasaran; dan jasa) dibangun secara simultan dan harmonis.

Upaya tersebut merupakan kegiatan yang sangat membutuhkan sinergisme dan kordinasi yang mantap baik dari aspek perencanaan, pelaksanaan, maupun pemanfaatan sumberdaya yang ada (SDM, SDA, dan Financial) agar tercipta suatu harmoni aktifitas yang membuahkan kesejahteraan masyarakat.

Dalam kaitan itulah, maka Laporan berikut di harapkan dapat memberikan gambaran tentang upaya-upaya yang telah dilakukan di Propinsi Riau dalam rangka mengembangkan konsep AGROPOLITAN. Serta mencoba menyajikan berbagai potensi yang dimiliki dan permasalahan yang dihadapi dalam upaya mengembangkan kawasan Agropolitan di Riau. 


\section{Maksud dan Tujuan}

\section{a. Maksud}

Memberikan gambaran bagi pihak-pihak terkait dalam rangka pengelolaan \& pengembangan kawasan agropolitan di Propinsi Riau.

b. Tujuan yang ingin dicapai adalah :

a Inventarisasi dan identifikasi potensi dan permasalahan pengembangan kawasan agropolitan di Propinsi Riau;

b Inventarisasi Kegiatan-kegiatan yang dilakukan di Kawasan Agropolitan semenjak program di laksanakan.

\section{B . MODEL PENGEMBANGAN AGROPOLITAN}

\section{Fokus Pengembangan}

Pengembangan Konsep Agropolitan dalam rangka memacu Kesejahteraan Masyarakat desa dilakukan dengan 3 Fokus Pengembangan sebagai dasar untuk menentukan strategi yang digunakan. Ketiga Fokus Pengembangan tersebut adalah :

a. Pengembangan dilakukan dengan pemberdayaan masyarakat agar mampu mengembangkan usaha komoditi unggulan berdasarkan kesesuaian kemampuan lahan dan kondisi sosial budaya daerah. Pemberdayaan masyarakat diarahkan pada usaha dengan sistem agribisnis lainnya yang mendukung usaha agribisnis komoditi unggulan kawasan agropolitan yaitu agribisnis hulu (agroinput) agribisnis hilir (pemasaran, pengolahan hasil, sortasi dan grading) serta industri jasa dan pelayanan.

b. Pengembangan sarana-prasarana publik yang berwawasan lingkungan yang diperlukan seperti jaringan jalan, irigasi transportasi, telekomunikasi, pasar, gudang dan kegiatan-kegiatan untuk memperlancar pengangkutan hasil pertanian ke pasar dengan efisien dan resiko minimal.

c. Reformasi regulasi yang berhubungan dengan penciptaan iklim kondusif bagi pengembangan usaha, pengembangan ekonomi daerah dan 
wilayah seperti dalam hal perizinan, bea masuk, peraturan dari pemerintah pusat, provinsi dan kabupaten/kota yang harus saling mendukung dan konsisten, dan menghilangkan regulasi yang saling menghambat.

\section{Arah Pengembangan}

Dengan Fokus pengembangan seperti tersebut di atas maka arah pengambangan dilakukan melalui upaya-upaya sebagai berikut :

a. Pemberdayaan masyarakat pelaku agribisnis di dalamnya termasuk peningkatan kualitas pengusaha (petani dan aparatur), sehingga mampu memanfaatkan potensi/peluang ekonomi yang ada di pedesaan.

b. Meningkatkan agribisnis komoditi unggulan lokalitas, yang saling mendukung dan menguatkan, termasuk usaha industri kecil,

c. pengolahan hasil, jasa pemasaran dan agrowisata dengan mengoptimalkan manfaat sumberdaya alam, secara efisien dan ekonomis, sehingga tidak ada limbah yang terbuang, atau yang tidak dimanfaatkan untuk kesejahteraan masyarakat (usaha pertanian terpadu tanpa limbah/Zero Waste).

a. Menjamin tersedianya sarana produksi dan permodalan pertanian dengan enam tepat (jumlah, kualitas, jenis, waktu, harga dan tempat).

b. Pengembangan Kelembagaan Petani sebagai sentra pembelajaran dan pengembangan agribisnis.

c. Pengembangan lembaga keuangan (Lembaga Keuangan Mikro).

d. Pengembangan kelembagaan penyuluhan pertanian menjadi Balai Penyuluhan Pembangunan Terpadu.

e. Pengembangan pusat-pusat pertumbuhan agribisnis dan industri pertanian secara lokalitas.

f. Peningkatan perdagangan/pemasaran termasuk pengembangan terminal/sub-terminal agribisnis dan pusat lelang hasil pertanian.

g. Meningkatkan pembangunan dan pemeliharaan sarana dan prasarana umum yang bersifat strategis.

h. Pengembangan pendidikan pertanian untuk generasi muda. 
i. Pengembangan percobaan/pengkajian teknologi tepat guna yang sesuai kondisi lokalitas.

\section{Strategi Pengembangan Agropolitan}

Ada 5 Strategi yang digunakan dalam pengembangan Kawasan Agropolitan yaitu :

\section{a. Pengembangan Sumberdaya Manusia (SDM)}

Sebagai titik masuk (entry point) dari pemberdayaan SDM di Kawasan Agropolitan adalah menyadarkan mereka sekaligus menumbuhkan rasa percaya diri mereka, bahwa tingkat pendapatan dan kesejahteraan yang mereka miliki sekarang masih bisa ditingkatkan. Dengan kesadaran dan percaya diri akan tumbuh motivasi dikalangan masyarakat untuk maju, sehingga mereka akan lebih mudah menerima dan tanggap terhadap setiap perubahan yang dianjurkan (tahap I dan tahap III).

Pembinaan manusia sementara diarahkan kepada SDM yang memiliki 4 (empat) sifat (catur gatra), yaitu : berbudi pekerti luhur, tekun dan kerja keras, maupun kerjasama dan memiliki sifat inovatif (lihat Gambar 1).

\section{Gambar 1}

\section{Strategi Pengembangan SDM}

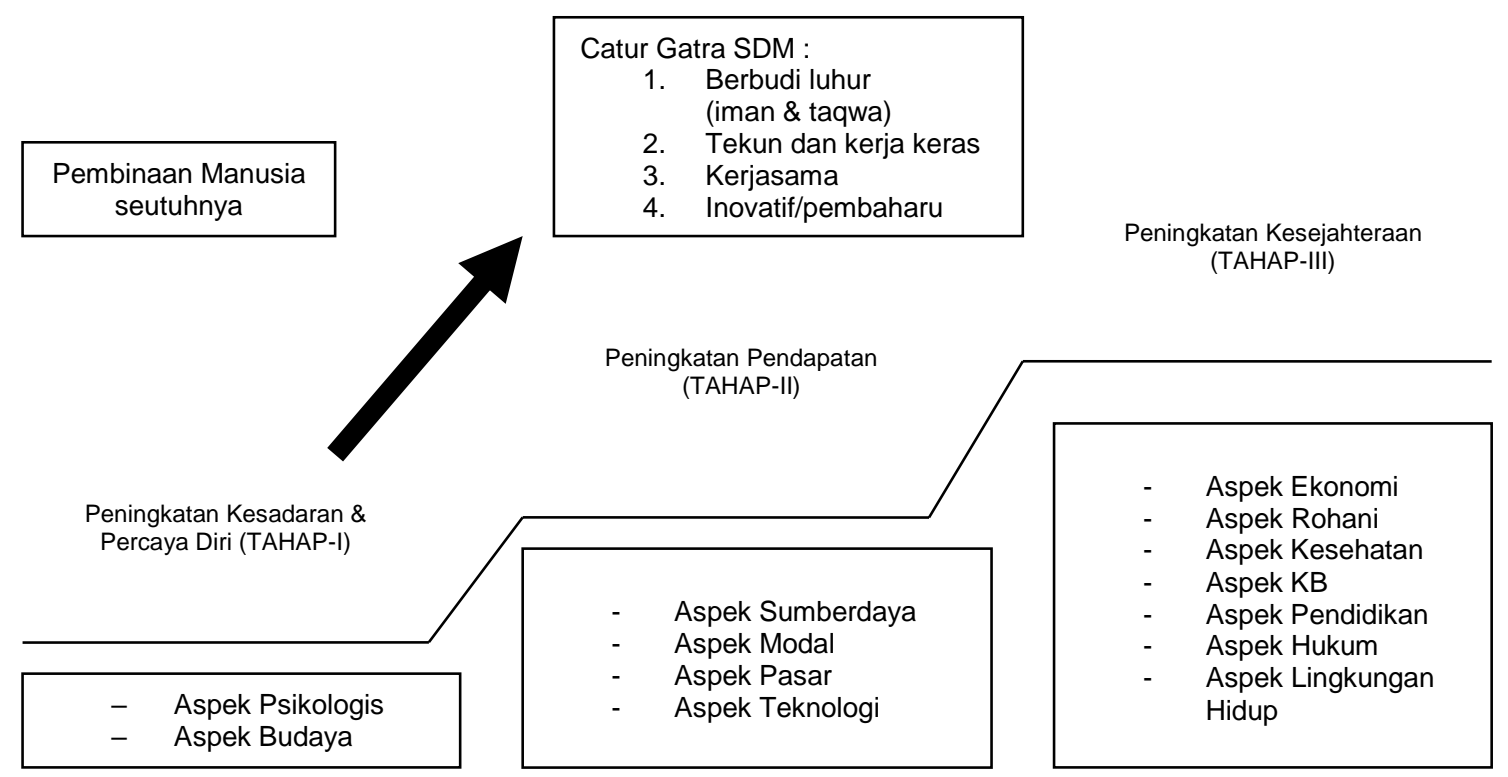




\section{b. Pengembangan Permodalan}

Bagi desa-desa yang belum banyak tersentuh oleh pembangunan; terutama pembangunan ekonomi, dimulai dengan berbagai bantuan dalam bentuk Bantuan Cuma-cuma atau Bantuan Bergulir. Bantuan yang diberikan didasarkan atas kebutuhan yang benar-benar dirasakan oleh masyarakat setempat, bukan bantuan yang diberikan secara begitu saja. Untuk itu terlebih dahulu haruslah dilakukan identifikasi dan analisa kebutuhan masyarakat (petani), dan atas dasar hasil analisa kebutuhan itulah maka bantuan itu diberikan. Bagi desa-desa yang sudah banyak tersentuh pembangunan, bantuan permodalan bagi usaha ekonomi masyarakat sudah dapat diberikan dalam bentuk Kredit Subsidi atau Kredit Komersial dengan kemudahan khusus (tanpa jaminan dan prosedurnya mudah). Kredit ini hendaknya tidak dibatasi untuk usaha budidaya saja, tapi bisa digunakan untuk segala macam usaha baik on-farm (budidaya) maupun off-farm seperti usaha sarana-prasarana produksi pertanian, pengolahan hasil pertanian, perdagangan maupun pelayanan jasa keuangan/simpan pinjam. Perjanjian kredit atau perjanjian lain yang terkait dengan kegiatan pemberdayaan, hendaknya diketahui atau merupakan tanggung jawab keluarga.

Akhirnya apabila sudah beberapa kali mampu mengembalikan Kredit Komersial ini dengan lancar, maka kita tingkatkan pada Kredit Komersial Penuh. Dengan cara demikian maka kita berhasil mendidik mereka menjadi mandiri dalam kebutuhan permodalan usaha. Artinya, apabila mereka membutuhkan tambahan modal bagi pengembangan usahanya mereka mampu berhubungan dengan bank (lembaga keuangan formal) sendiri dan mampu memenuhi persyaratan bank /bank-able (lihat Gambar 2). 


\section{Gambar 2 \\ Strategi Pengembangan Permodalan}

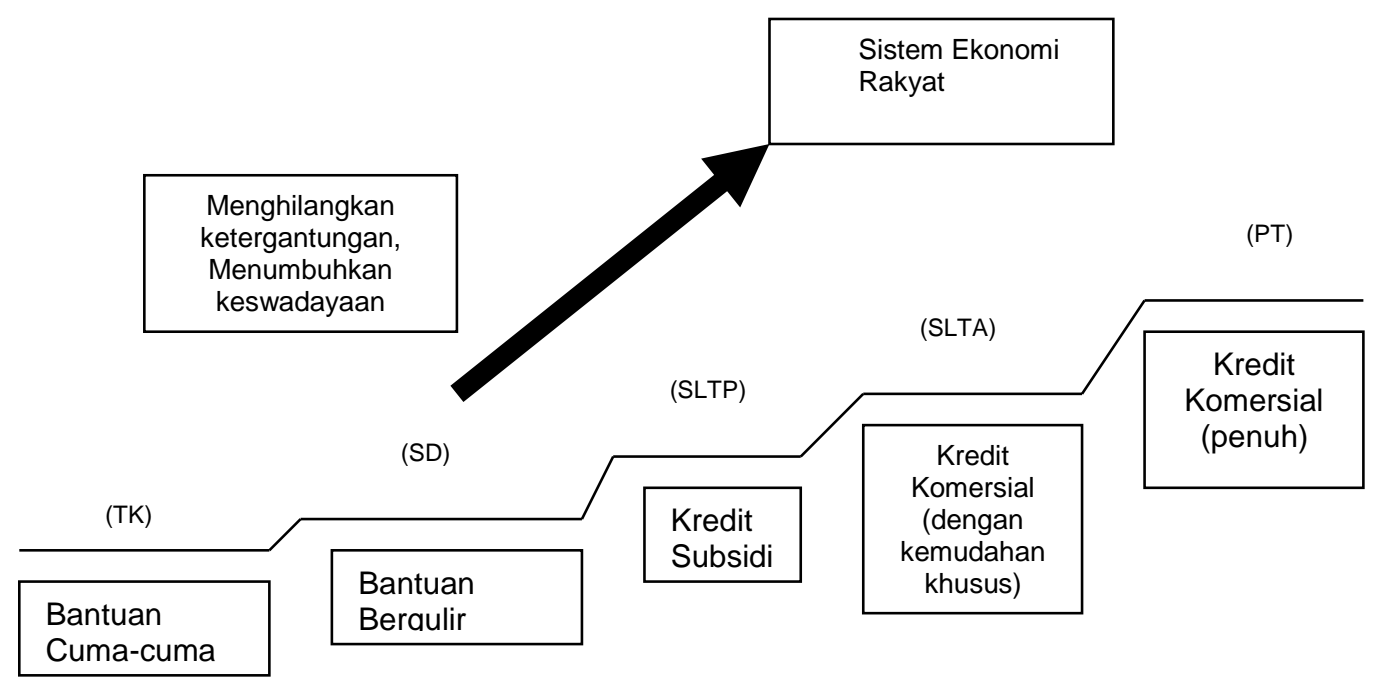

\section{c. Pengembangan Kelembagaan Ekonomi Rakyat}

Strategi ketiga dalam upaya meningkatkan pendapatan dan kesejahteraan masyarakat di kawasan Agropolitan adalah dikembangkannya Kelembagaan Ekonomi masyarakat yaitu suatu kelembagaan yang tumbuh dari, oleh dan untuk kepentingan masyarakat, bukan kelembagaan yang dibentuk untuk kepentingan Instansi Pembina. Ini sangat penting, karena hanya kelembagaan yang tumbuh dari bawah itulah yang akan mampu berkembang secara berkelanjutan. Secara skematis upaya pengembangan kelembagaan ekonomi rakyat dapat digambarkan sebagai berikut (Lihat Gambar 3).

Seperti diketahui, Ekonomi Rakyat adalah suatu usaha ekonomi yang dijalankan oleh rakyat banyak dan jenisnya sangat beragam mulai dari usaha tani dilahan sempit, mengolah hasil pertanian, kerajinan, jual beli hasil pertanian dsb. Mereka pada umumnya berusaha sendiri-sendiri dengan keterampilan dan modal seadanya. Itulah dunia ekonomi yang banyak dijalankan oleh masyarakat banyak, yang sangat membutuhkan uluran tangan untuk menolongnya agar kesenjangan antara "Ekonomi Rakyat" dan "Ekonomi Konglomerat" tidak semakin membesar. 


\section{Gambar 3}

Strategi Pengembangan Kelembagaan Ekonomi Rakyat

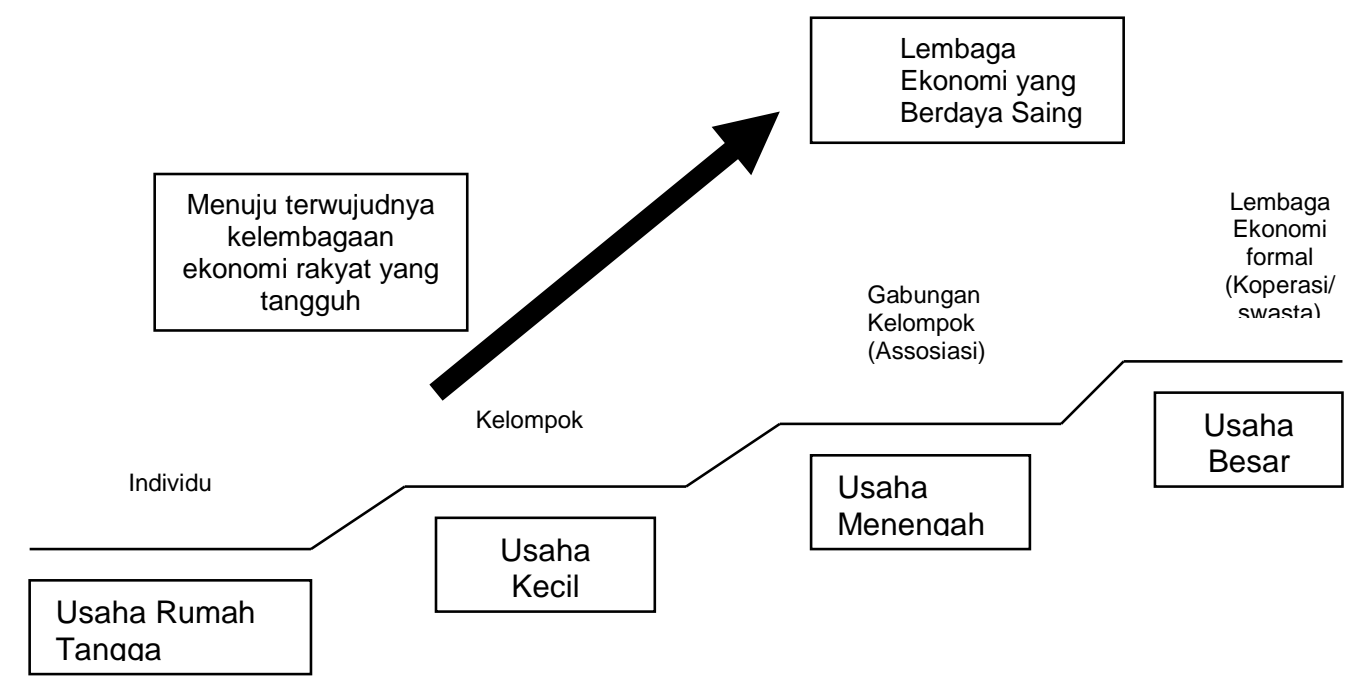

Langkah pertama dari strategi ini adalah mereka yang semula berusaha sendiri-sendiri (usaha rumah tangga), kita dorong dan bimbing agar mereka mampu bekerjasama di bidang ekonomi secara berkelompok. Usaha tetap dijalankan di masing-masing keluarga, hanya mungkin ada aspek yang dikerjasamakan dalam kelompok ( sebagai faktor pengikat), seperti pengadaan bahan baku bersama, menjual hasil bersama, mendapatkan modal bersama, dan sebagainya. Anggota kelompok haruslah terdiri dari para petani/pengusaha yang saling mengenal, saling percaya dan mempunyai kepentingan yang sama (ada faktor pengikat/binding faktor), sehingga akan tumbuh kerjasama yang kompak dan serasi.

Langkah selanjutnya adalah menumbuhkan Gabungan Kelompok atau sering juga disebut sebagai Asosiasi. Kelompok-kelompok yang sudah tumbuh dan berjalan secara baik; terutama kelompok-kelompok yang usahanya sejenis seperti : peternak ayam/bebek, pedagang hasil bumi, pengrajin anyaman bambu atau makanan ringan, petani palawija/sayuran, didorong dan dibimbing agar mereka mau dan mampu bekerjasama antar kelompok, dalam bentuk organisasi yang lebih besar yang disebut Gabungan Kelompok atau Asosiasi. 
Tujuan dari ditumbuhkannya Gabungan Kelompok ini adalah dalam rangka mengembangkan kerjasama ekonomi yang lebih luas, sehingga dapat memberikan manfaat yang lebih besar bagi para anggotanya.

Manfaat itu umpamanya dapat dilihat dalam :

a. Menghimpun modal usaha yang lebih besar

b. Memperbesar skala usaha

c. Memperkuat posisi tawar menawar

d. Meningkatkan efisiensi dan efektifitas usaha.

Gabungan Kelompok atau Asosiasi ini kalau sudah berjalan lancar dan baik, kita dorong dan bimbing lagi agar mereka mau dan mampu menjadi salah satu lembaga ekonomi formal dan yang paling tepat tentunya adalah Koperasi. Untuk mencapai itu perlu dilakukan berbagai kegiatan advokasi dan bimbingan, agar mereka benar-benar memahami apa manfaatnya menjadi suatu lembaga ekonomi formal (koperasi).

\section{d. Pengembangan Usaha Agribisnis}

Secara umum usaha agribisnis memerlukan tahapan perkembangan terutama bila dikaitkan dengan tingkat kemampuan sumberdaya manusianya dan penggunaan sumberdaya alam yang secara skematis tahapan tersebut dapat digambarkan sebagai berikut (lihat Gambar 4).

Para petani di Kawasan harus mampu menghitung atau menganalisis apakah usaha agribisnis yang diusahakannya menguntungkan atau tidak. Untuk dapat menguntungkan suatu usaha, maka petani harus dapat mengembangkan model usaha agribisnis yang efisien dan menguntungkan.

Lebih jauh, untuk meningkatkan kesejahteraan dan ketahanan pangan, petani harus menerapkan/pengembangan usaha pertanian (agribisnis) yang efisien dan menguntungkan yang dirancang dalam kapasitas skala ekonomi yang menguntungkan. Upaya tersebut harus dimulai dengan pemilihan komoditas-komoditas unggulan, yang kemudian dikembangkan pengelolaannya secara komplementer (saling melengkapi) serta didukung dengan pengembangan prosessing, sortasi, pengepakan, pemasaran, 
Industri kecil, industri jasa yang sesuai dengan kondisi daerah dan masyarakatnya.

\section{Gambar 4 \\ Strategi Pengembangan Usaha Agribisnis}

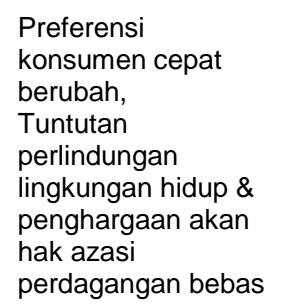

2. Tenaga kerja yang tidak terdidik

3. Peningkatan nilai produksi

masih bersumber dari

peningkatan jumlah pengguna

SDA dan Tenaga Kerja

\section{e. Pengembangan Sarana-Prasarana dan Iklim Usaha}

Pengembangan sarana-prasarana publik yang berwawasan lingkungan yang diperlukan seperti jaringan jalan, irigasi, transportasi, telekomunikasi, pasar, gudang dan kegiatan-kegiatan untuk memperlancar pengangkutan hasil pertanian ke pasar dengan efisien dan resiko minimal. Sarana dan Prasarana utama yang perlu dilengkapi di Kawasan Agropolitan adalah :

\section{1) Pasar}

Usaha yang dikembangkan sudah mengandalkan:

Pemanfaatan sumberdaya lokal terpadu

Kekuatan investor

Pengembangan agribisnis hilir

Peningkatan kemampuan SDM
Usaha Agribisnis (Tahap 3)

saha yang dikembangkan mengandalkan :

Optimalisasi sumberdaya

pengembangan sistem usaha

agribisnis

Kekuatan investasi melalui

kemajuan teknologi

Kemampuan SDM yang tinggi

Fungsi pasar adalah sebagai penyedia sarana yang dibutuhkan serta sebagai tempat memasarkan hasil usaha tani. Karena fungsinya yang demikian sangat diperlukan, maka adanya pasar di daerah pengamatan 
yang letaknya strategis yang dapat mengakses keseluruh wilayah agropolitan.

2) Lembaga Keuangan

Lembaga keuangan adalah salah satu lembaga ekonomi sebagai penyedia modal bagi masyarakat usaha tani. Dengan demikian sangatlah diperlukan keberadaannya. Sebagai lembaga ekonomi masyarakat yang sangat diperlukan, maka tingkat pelayanannya terhadap pemenuhan kebutuhan modal usaha bagi masyarakat adalah ditentukan oleh kapasitas modal yang dimiliki, kemudahan pelayanan serta jangkauan wilayah kerja lembaga keuangan dimaksud.

Pada proses awal pengembangan kawasan agropolitan yang dibutuhkan adalah lembaga keuangan yang menyediakan dana dengan tingkat suku bunga rendah atau tingkat suku bunga yang tersubsidi.

\section{3) Percobaan/Pengkajian Teknologi}

Dalam upaya meningkatkan produksi dan kemampuan masyarakat dalam usaha tani, maka diperlukan suatu pengembangan dan pemasyarakatan teknologi pertanian. Pengembangan teknologi juga frekuensi penerapan (pemasyarakatan) yang dilakukan diantaranya demontrasi cara (Demplot) dan lain sebagainya.

\section{4) Kelembagaan Tani}

Kelembagaan tani sebagai suatu wadah dalam mendinamisasikan kegiatan usahatani diperlukan keberadaannya. Kelembagaan tani yang baik adalah kelembagaan yang dapat menggerakkan, mengkoordinasikan anggotanya dalam kegiatan usahatani. Oleh karena itu kelembagaan tani baik formal dan informal sangat diperlukan keberadaannya di daerah pengamatan.

5). Infrastruktur

Infrastruktur yang terdiri dari jaringan jalan dan irigasi adalah sangat penting keberadaannya. Untuk jaringan irigasi fungsinya sebagai 
pengatur pemenuhan kebutuhan air di dalam proses budidaya dan penanganan hasil (pencucian) ini mutlak sangat diperlukan. Kemudian jaringan jalan (transportasi) yang baik (layak) guna menunjang kelancaran pengangkutan produksi serta komunikasi usaha. Disamping itu pula tingkat aksesibilitas daerah inti agropolitan dengan kawasan sekitarnya sangat ditentukan oleh kelayakan jaringan jalan.

\section{PROFIL KAWASAN AGROPOLITAN DI PROPINSI RIAU}

\section{Kabupaten Indragiri Hilir :}

a. Dasar Hukum :

1) Surat Menteri Pertanian Nomor 312/TU.210/A/X/2002, Tanggal 16 Oktober 2002, Tentang Program Rintisan Kawasan Agropolitan Tahun 2003

2) SK Bupati Nomor Kpts.30///HK-2003, Tanggal 28 Januari 2003, Tentang Pembentukan Kelompok Kerja Pengembangan Kawasan Agropolitan Kabupaten Indragiri Hilir.

\section{b. Karakteristik Fisik Dasar Lokasi}

Secara geografis KABUPATEN INDRAGIRI HILIR di posisi $0^{\circ} 36^{\prime}$ LU 1ㅇ $07^{\prime}$ LS dan 104 $10^{\prime}$ BB - 102 $32^{\prime}$ BB.

Kawasan Agropolitan terletak di 3 Kecamatan yaitu Kecamatan Tempuling, Tembilahan dan Tembilahan Hulu, terdiri dari 25 Desa/Kelurahan dengan luas Kawasan 1.401,68 Km².

Kabupaten indragiri Hilir secara umum memiliki jenis tanah Organosol, Histosol, dan aluvial. Memiliki iklim tropis basah dengan curan hujan adalah $2.300 \mathrm{~mm}$ per tahun dengan rata-rata hari hujan 9 hari perbulan, dan rata-rata suhu $35^{\circ} \mathrm{C}$.

\section{c. Pengembangan Areal Pertanian di Kawasan :}

Sesuai dengan pembangunan wilayah dalam penyusunan Master Plan maka ketiga kecamatan dibagi dalam kawasan sebagai berikut : 
1) BWKA I:

Pengembangan areal pertanian yang meliputi Desa/Kelurahan, Bayas Jaya, Pekan Tua, Kempas Jaya, Sungai Gantang, Rumbai Jaya, sungai Ara, Harapan Tani, dan Desa Karya Tani dengan Luas 847,62 Km²

2) BWKA II

Meliputi Desa/Kelurahan, Harapan Jaya, Karya Tunas Jaya, Teluk Kiambang, Mumpa, Teluk Jira, Sungai Salak dan Tempuling.

3) BWKA III

Meliputi Desa/Kelurahan, Pulau Palas, Pekan Kamis, Sialang Panjang, Pekan Arba, Sungai Beringin, Seberang Tembilahan dan Sungai Perak.

Dalam Pengembangan kawasan Agropolitan Komoditi Prioritas utama yang dikembangkan adalah Padi dan Kelapa. Selain itu Komoditas Unggulan lainnya yang dikembangkan adalah Jeruk dan Pisang.

\section{d. Kependudukan}

Jumlah Penduduk di Tiga Kecamatan tersebut adalah 79.541 jiwa dengan jumlah Rumah Tangga miskin sebanyak 10.746 KK. Kepadatan penduduk rata-rata 56,75 penduduk $/ \mathrm{Km}^{2}$ dan sex ratio adalah 1,03 .

\section{e. Karakteristik Perekonomian}

Kegiatan ekonomi penduduk di Kawasan Agropolitan Indragiri Hilir adalah di bidang pertanian dan Perkebunan di Kecamatan Tempuling 69,97\%, Kecamatan Tembilahan Hulu 72,32 \% dan Kecamatan Tembilahan 40,57 \% penduduk yang bekerja di usaha Pertanian/Perkebunan.

\section{f. Sarana dan Prasarana}

Di Kawasan Agropolitan Indragiri Hilir terdapat 10 Buah Pasar lokal, dengan demikian belum semua desa memiliki pasar.

Dari seluruh desa/kelurahan ada 16 Desa yang belum mendapat pelayanan $\mathrm{i}$ Listrik dari PLN.

Sarana Pendidikan di Kawasan 2 buah TK, 98 SD/MI, 17 SMP/MTs, dan 5 SMU/MAN. 


\section{Jaringan Jalan}

Secara umum Ibu desa/Kelurahan kawasan agropolitan dapat dicapai dengan transportasi darat kecuali kelurahan Seberang Tembilahan, Sungai Perak yang ada di seberang Sungai Indragiri, harus menggunakan transportasi air (pompong), kemudian dilanjutkan dengan transportasi darat roda dua. Jalan lingkungan, jalan usaha tani, jalan poros desa yang ada, umumnya masih jalan tanah yang merupakan hasil galian dari pembuatan kanal.

\section{g. Gambaran Umum Kawasan :}

Upaya pengembangan telah dilakukan 2 tahun berjalan, namun sinergisme kegiatan belum sepenuhnya terjadi baik dalam penyusunan perencanaan, maupun dalam aktifitas pengembangan/pembangunan kawasan di lapangan.

Secara umum terdapat peningkatan alokasi pendanaan dan aktifitas di lapangan baik dalam peningkatan infrastruktur maupun dalam penanaman modal oleh investor dengan bertambahnya Usaha Pengolahan Hasil (Pembangunan Pabrik) yang dilakukan oleh pihak swasta. Namun aktifitas masyarakat belum mampu secara nyata di pacu dengan kegiatan-kegiatan yang dilakukan.

Upaya membangun institusi pelaksana di tingkat lapangan terus dilakukan baik oleh Pusat maupun Propinsi namun belum membuahkan hasil di tingkat lapangan, sehingga koordinasi kegiatan di tingkat lapangan belum sepenuhnya terwujud.

\section{Kabupaten Rokan Hulu :}

\section{a. Dasar Hukum Lokasi}

1) SK Bupati Nomor : Kpts.520/PERTANIAN/99/2004, Tanggal 13 Desember 2004, Tentang Pembentukan Kelompok Kerja Pengembangan Kawasan Agropolitan Kabupaten Rokan Hulu.

2) SK Bupati Nomor : Kpts.520/PERTANIAN/100/2004, Tanggal 13 Desember 2004, Tentang Penetapan Lokasi, Daerah Kawasan, 
Komoditas Unggulan dan Andalan Pengembangan Kawasan Agropolitan Kabupaten Rokan Hulu.

\section{b. Karakteristik Fisik Dasar}

Secara geografis KABUPATEN ROKAN HULU di posisi $0^{\circ} 62^{\prime}$ LU - $1^{\circ}$

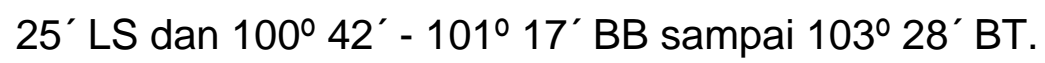

Kawasan Agropolitan terletak di Kecamatan Rambah Samo dengan luas wilayah $249,9 \mathrm{Km}^{2}$ terdiri dari 9 desa/kelurahan.

Jenis tanah secara umum di Rokan Hulu terdiri dari PMK, Organosol, Litosol, Regosol, dan Histosol. Topografi umumnya merupakan dataran rendah dengan ketinggian daerah berkisar antara 70 - 86 meter di atas permukaan laut.

Kawsan Agropolitan memiliki iklim tropis dengan suhu rata-rata 31 $32^{\circ} \mathrm{C}$. Dengan curah hujan rata-rata $2.313 \mathrm{~mm} /$ tahun.

\section{c. Pola Penggunaan Lahan \& Komoditas Yang di Kembangkan}

Komposisi penggunaan lahan Kecamatan Rambah Samo saat ini didominasi oleh kegiatan pertanian yaitu seluas $17.433 \mathrm{Ha}$.

Berdasaran SK Bupati, komoditas yang kembangkan sebagai Komoditas Unggulan adalah : Padi, Jagung, Kacang Tanah, dan Komoditas andalan adalah Salak Pondoh, Ternak, Kolam Ikan, dan Kelapa Sawit.

\section{d. Kependudukan}

Jumlah Penduduk Kecamatan Rambah Samo berjumlah 20.070 Jiwa dengan jumlah Rumah Tangga Miskin sebanyak 1.236 KK. Tingkat kepadatan penduduk $591 \mathrm{jiwa} / \mathrm{Km}^{2}$

Pertumbuhan ekonomi rata-rata di Kabupaten Rohul sampai tahun 2002 adalah $6,64 \%$

\section{e. Karakteristik Perekonomian}

Penyumbang terbesar terhadap PDRB adalah sektor Pertanian $(63,83$ \%). Tingkat pertumbuhan ekonomi rata-rata di Tahun 2002 adalah 6,64 \% 


\section{f. Sarana dan Prasarana}

Di Kawasan Agropolitan Rambah Samo terdapat 4 buah Pasar Umum, 364 Kios/Warung dan 5 KUD.

Sarana Transportasi menuju Kawasan dapat ditempuh melalui jalan darat.

Sementara di seluruh Desa telah terdapat sekolah Dasar, sementara SLTP terdapat 3 buah, dan 1 buah SMU.

Hampir separoh penduduk (47 \%) telah memanfaatkan dan mendapat jasa Listrik dari PLN.

\section{Jaringan Jalan}

Sarana jalan yang terdapat di kawasan sampai Tahun 2002 adalah 14 $\mathrm{Km}$ jalan aspal, $18 \mathrm{Km}$ jalan kerikil, dan $69 \mathrm{Km}$ jalan tanah.

\section{g. Gambaran Umum Pengembangan Kawasan}

Respon untuk pengembangan kawasan cukup baik di Kabupaten Rokan Hulu. Hal ini terlihat dari upaya yang dilakukan baik dimulai dari komitmen Pemerintah Kabupaten dengan dukungan legal formalnya (SK) maupun aspek perencanaan dengan tersusunnya Master Plan dengan menggunakan dana APBD Pemerintah Kabupaten (ABT 2004).

Aktifitas di kawasan belum sepenuhnya menunjukkan pengembangan, hal ini karena kegiatan baru dimulai tahun 2005, namun upaya ke arah pengembangan sesuai Master Plan telah banyak dilakukan, baik yang menyangkut aspek perencanaan, pendanaan, maupun dukungan dari berbagai pihak.

Institusi di Tingkat Lapangan belum tersedia, demikian juga Posko lapangan, diharapkan pada Tahun 2006 kondisi ini dapat terfasilitasi dengan baik sehingga partisipasi/keberdayaan masyarakat sebagai salah satu syarat pengembangan kawasan dapat dipenuhi.

\section{Kabupaten Kampar}

\section{a. Dasar Hukum Lokasi}


SK Bupati Nomor : 044 Tahun 2004, Tanggal 8 Maret 2004, Tentang Penetapan Lokasi Pengembangan Kawasan Agropolitan Kabupaten Kampar.

\section{b. Karakteristik Fisik Dasar}

Secara geografis KABUPATEN KAMPAR di posisi 1을 $02^{\prime} \mathrm{LU}-0^{\circ}=20^{\prime}$ LS dan 1002 BT sampai 101 40’ BT.

Kawasan Agropolitan terletak di Kualu Nenas, Kelurahan Pulau, dan Sekijang

\section{c. Pola Penggunaan Lahan dan komoditas Yang di kembangkan}

Berdasarkan SK Bupati Komoditas yang dikembangkan di Kawasan adalah : untuk Daerah Pusat Pertumbuhan (DPP) Kualu Nenas Komoditas Unggulan adalah Nenas dan Komoditas andalan adalah Jeruk, Rambutan, Manggis, Durian dan Padi. Daerah Pusat Pertumbuhan (DPP) Kelurahan Pulau Komoditas Unggulan adalah Padi dan komoditas andalan adalah Palawija, Sayur-Sayuran, Durian, dan Manggis. Daerah Pusat Pertumbuhan (DPP) Sekijang Komoditas Unggulan Kelapa Sawit, Komoditas andalan adalah Salak pondoh.

\section{d. Kependudukan}

Jumlah penduduk di Kabupaten Kampar sebanyak 532,498 jiwa dengan jumlah penduduk miskin sebanyak 122,504 jiwa (23.01\%) atau 30,626 KK.

\section{e. Gambaran Umum Pengembangan Kawasan}

Belum terlihat secara jelas instansi yang bertindak sebagai inisiator dalam pengembangan Kawasan Agropolitan di Kampar. Sampai saat ini belum ada terbentuk Kelompok Kerja baik di tingkat Lapangan maupun Kabupaten.

Pekerjaan DED (Detail Engineering Design) \& RPJM (Rencana Pengembangan Jangka Menengah) telah disusun dengan menggunakan dana Pusat. 
Sosialisasi kurang/belum dilaksanakan sehingga belum semua instansi terkait mengetahui Rencana Pengembangan Kawasan Agropolitan di Kabupaten Kampar.

\section{KEGIATAN PENGEMBANGAN S.D. 2005}

\section{Tahun 2003}

Pada Tahun 2003 Propinsi Riau memulai kegiatan Pengembangan kawasan Agropolitan. Beberapa kegiatan yang dilaksanakan untuk mendukung Program tersebut adalah :

a. Penetapan Kawasan Agropolitan oleh Menteri Pertanian bahwa Kawasan Agropolitan di Riau adalah Kabupaten Indragiri Hilir (Tempuling) dengan komoditas Utama Padi dan Kelapa dan Komoditas Unggulan lainnya adalah Pisang dan Jeruk.

b. Diklat APSUA (Akselerasi Pengembangan Sistem dan Usaha Agribisnis) Bagi Kepala Dinas, Kepala Balai Pelatihan Tanaman Pangan, dan Widyaiswara di Ciawi Bogor.

c. Diklat APSUA Bagi Kepala Dinas Lingkup Pertanian Kabupaten di Riau. Pelaksanaan Diklat APSUA adalah di Balai Pelatihan Tanaman Pangan Propinsi Riau (Bapeltan Riau).

d. Sosialisasi Agropolitan di Lingkungan Pemda Indaragiri Hilir di Tembilahan (Nara Sumber dari Jakarta/Pusat)

e. Ekspose Pengembangan Kawasan Agropolitan Indragiri Hilir oleh Kepala Dinas Tanaman Pangan dan Hortikultura Inhil di Bapeltan Riau, Pekanbaru.

f. Pembentukan Kelompok Kerja (Pokja) Pengembangan Kawasan Agropolitan beserta Seretariat Kelompok Kerja

g. Penyusunan Master Plan Kawasan Agropolitan Kabupaten Indragiri Hilir Jangka waktu 2004 - 2008 (5 tahun). Dana Sharing APBN dan APBD Kabupaten Indragiri Hilir

h. Pembangunan Jalan Usaha Tani dan Jalan Poros Desa, Dana APBN

i. Penyusunan Draft Kelompok Kerja Agropolitan Propinsi Riau. 


\section{Tahun 2004}

Pada Tahun 2004 Gubernur Riau menerbitkan Surat Keputusan Pembentukan Kelompok Kerja Pengembangan Kawasan Agropolitan Propinsi Riau.

Sejalan dengan itu Kawasan Agropolitan di tambah di 2 Kabupaten yaitu Kabupaten Kampar ditandai dengan SK Bupati tentang Penetapan Lokasi Pengembangan Kawasan Agropolitan Kabupaten Kampar. Namun Pengembangan Kawasan di Kabupaten Kampar belum ditindak lanjuti secara baik.

Kabupaten Lain yang dikembangkan Kawasan Agropolitan adalah Kabupaten Rokan Hulu di tandai dengan SK Bupati tentang Penetapan Lokasi, Daerah Kawasan, dan Komoditas Unggulan dan Andalan, Serta SK Bupati tentang Pembentukan Kelompok Kerja Pengembangan Kawasan Agropolitan.

Selanjutnya Kabupaten Rokan Hulu melalui dana ABT APBD Kabupaten menyusun Master Plan.

Sepanjang Tahun 2004 di daerah pengembangan Kawasan Agropolitan dilakukan berbagai kegiatan, Kegiatan yang berhasil di inventarisir dari berbagai instansi oleh Sekretariat Pokja Agropolitan Propinsi Riau adalah sebagaimana terlihat pada Tabel 1 berikut.

\section{Tahun 2005}

Pada Tahun 2005 Sekretariat Kelompok Kerja Agropolitan Propinsi Riau melakukan inventarisasi kegiatan yang dilaksanakan di Kawasan Agropolitan, dan daftar hasil inventarisasai kegiatan dapat dilihat pada Tabel 2, 3 dan 4.

Disamping itu Sekretariat Kelompok Kerja sepanjang Tahun 2005 melaksanakan kegiatan sebanyak 13 Kegiatan, namun karena pertimbangan administrasi dan teknis tidak seluruh kegiatan dapat terealisasi dengan sempurna. 
Daftar kegiatan dan realiasi kegiatan yang dilaksanakan oleh sekretariat Kelompok Kerja Agropolitan Propinsi Riau adalah sebagai berikut :

\begin{tabular}{|l|l|r|l|r|r|}
\hline No. & \multicolumn{1}{|c|}{ Kegiatan } & Jumlah Dana & \multicolumn{1}{|c|}{ Volume } & $\begin{array}{r}\text { Real } \\
\text { Fisik } \\
(\%)\end{array}$ & Real Keuangan \\
\hline 1. & Pelaksana kegiatan & $10.000 .000,-$ & 1 org, 1 thn & 70 & 0 \\
\hline 2. & Sekr. Dukungan & $211.515 .250,-$ & 1 tahun & 80 & $153.040 .250,-$ \\
\hline 3. & KKA dan PIA & $151.927 .000,-$ & 1 tahun & 100 & $150.237 .000,-$ \\
\hline 4. & Rembug KTNA & $34.250 .000,-$ & 30 org,3 hr & 100 & $25.537 .150,-$ \\
\hline 5. & $\begin{array}{l}\text { Lat. Penguatan Ke- } \\
\text { lemb. Bg.PP.Swa. }\end{array}$ & $130.000 .000,-$ & $\begin{array}{l}60 \text { org, } \\
5 \text { hari }\end{array}$ & 100 & $96.981 .800,-$ \\
\hline 6. & Mimbar Sarasehan & $77.460 .000,-$ & 50 org,4 hr & 100 & $55.996 .650,-$ \\
\hline 7. & $\begin{array}{l}\text { Lat. Kewiraushaan } \\
\text { bagi Petani. }\end{array}$ & $151.199 .000,-$ & $\begin{array}{l}50 \text { org, } \\
10 \text { hari }\end{array}$ & 100 & $122.157 .827,-$ \\
\hline 8. & $\begin{array}{l}\text { Lat. Adm. \& Kau bg } \\
\text { pengurus kelompok }\end{array}$ & $159.998 .750,-$ & 125 org, & 100 & $128.498 .750,-$ \\
\hline 9. & $\begin{array}{l}\text { Lat. APSUA bg. } \\
\text { Kades \& Tomas }\end{array}$ & $75.000 .000,-$ & $\begin{array}{l}30 \text { orang, } \\
7 \text { hari }\end{array}$ & 100 & $57.865 .000,-$ \\
\hline 10. & Lat. PRA bg Tomas & $241.675 .000,-$ & 150 org,7hr & 86,8 & $209.705 .300,-$ \\
\hline 11. & Studi Banding & $151.400 .000,-$ & 1 Paket & 100 & $151.399 .350,-$ \\
\hline 12. & Percontohan & $61.575 .000,--$ & 3 Paket & 20 & $6.950 .000,-$ \\
\hline 13. & Konsultas/pertemua & $38.400 .000,-$ & & 100 & $31.800 .000,-$ \\
\hline & JUMLAH & $\mathbf{1 . 4 9 4 . 4 0 0 . 0 0 0}$ & & $1.190 .169 .077,-$ \\
\hline & & & & & \\
\hline
\end{tabular}

\section{E. MASALAH DAN PEMECAHAN MASALAH}

\section{Masalah}

a. Umum :

1) Masih lemahnya koordinasi dan sinkronisasi diantara sektor atau subsektor baik di Tingkat Kabupaten maupun Propinsi.

b. Kabupaten Indragiri Hilir : 
1) Dukungan Pemerintah Daerah setempat belum optimal.

2) Kegiatan di Lapangan belum terkoordinir secara baik, sehingga banyak kegiatan tidak termonitor secara baik.

3) Petugas yang ditunjuk sebagai petugas Posko, tidak melaksanakan tugas secara baik, karena penunjukan petugas kurang jelas.

4) Lambatnya administrasi keuangan sehingga pelaksanaan kegiatan menjadi tergesa-gesa.

5) Infrastruktur belum memadai sehinga tidak dapat memacu/ mendorong petani untuk memproduksi lebih baik, karena persoalan mobilisasi agroinput maupun hasil produksi.

6) Kelompok Tani belum berfungsi maksimal sebagai wadah belajar dan kerja sama dalam berusaha.

c. Kabupaten Rokan Hulu

1) Sosialisasi Master Plan belum mencapai seluruh masyarakat.

2) Posko tingkat lapangan belum ada

d. Kabupaten Kampar

1) Kelompok Kerja Kabupaten Belum ada, sehingga menyulitkan koordinasi kegiatan.

2) Dinas inisiator belum jelas.

3) Sosialisasi kegiatan belum terlaksana, baik di Tingkat Pemerintah Kabupaten maupun Masyarakat.

\section{Pemecahan Masalah}

a. Umum :

1) Sekretariat Pokja berusaha semaksimal mungkin menginventarisir dan menginformasikan kegiatan kepada instansi terkait.

2) Mengadakan pertemuan-pertemuan baik di Tingkat Pokja Propinsi maupun Sekretariat Pokja Kabupaten.

b. Kabupaten Indragiri Hilir : 
1) Mendorong Dinas Tanaman Pangan untuk lebih memfokuskan pengembangan kawasan.

2) Menginventarisir kegiatan yang dilaksanakan di kawasan dan menginformasikan kepada Dinas Instansi terkait.

3) Berkoordinasi dengan sekretariat Pokja Kabupaten.

4) Menginventarisir kegiatan yang dapat dilaksanakan lebih awal, sepanjang tidak menyalahi administrasi dan keuangan.

5) Menyarankan kepada Dinas Instansi terkait agar mengalokasikan dana untuk peningkatan infrastruktur kawasan.

6) Melaksanakan Pelatihan-pelatihan kepada Kelompok Tani/petani di Kawasan.

c. Kabupaten Rokan Hulu

1) Menginformasikan Program kepada Masyarakat disetiap kesempatan yang memungkinkan.

2) Menyarankan kepada Sekretariat Pokja Kabupaten agar memfasilitasi pembentukan Posko di Tingkat Lapangan.

d. Kabupaten Kampar

1) Berusaha menyarankan Pemerintah Kabupaten untuk membentuk Kelompok Kerja Kabupaten.

2) Mengagendakan Sosialisasi kepada pemerintah Kabupaten di Tahun 2006.

\section{F. KESIMPULAN DAN SARAN}

\section{Kesimpulan}

a. Komoditi unggulan pertanian di Kawsan Agropolitan Indragiri Hilir adalah Padi. Kelapa, dan Komoditi Pendukung adalah Jeruk dan Pisang, sedangkan di kawasan Agropolitan Rokan Hulu yaitu padi, Jagung, Kacang Tanah, dengan komoditas andalan Salak Pondoh, Sawit, Ternak dan Kolam Ikan. Dan di Kabupaten Kampar Komoditas Unggulan Utama adalah Nenas, Padi, dan Kelapa Sawit, serta Komoditas pendukung 
adalah Jeruk, Rambutan, Durian, Manggis, Salak Pondoh, Palawija dan Sayuran.

b. Kelembagan yang ada belum optimal sebagai pemacu pengembangan kawasan.

c. Prasarana transportasi (jaringan jalan) dan jumlah panjang jalan desa di lokasi agropolitan belum memadai. Untuk itu perlu upaya peningkatan kualitas jaringan jalan.

d. Potensi Kawasan untuk dikembangkan sebagai Kawasan Agropolitan cukup memadai, namun upaya pengembangan perlu dilakukan koordinasi yang baik.

e. 2 Kabupaten (Indragiri Hilir \& Rokan Hulu) telah memiliki Kelompok Kerja Agropolitan, sementara Kabupaten Kampar belum. Di Tingkat Lapangan ke tiga Kabupaten belum memiliki institusi/lembaga/Posko/Kelompok kerja sebagai alat sinkronisasi dan koordinasi kegiatan Agropolitan.

\section{Saran}

a. Perlu adanya peningkatan kualitas dan kuantitas jalan dilokasi pengembangan agropolitan dengan klasifikasi sesuai kebutuhan minimal kontruksi jalan.

b. Perlu adanya peningkatan fungsi Lembaga yang ada sebagai institusi penggerak pengembangan kawasan, maupun pemicu pengembangan sistem dan usaha agribisnis.

c. Perlu peningkatan penguatan modal usaha ekonomi agribisnis dengan memberdayakan kelembagaan keuangan yang ada.

d. Semangat dasar dari kebijakan agropolitan adalah proses penciptaan nilai tambah di kawasan perdesaan oleh masyarakatnya sendiri. Dengan demikian diperlukan integrasi setiap unsur terkait agar dapat berjalan secara sinergis.

e. Perlu uapaya-upaya penguatan kapasitas masyarakat lokal. Penguatan kapasitas masyarakat harus diupayakan terbentuk secara berkelanjutan dan tidak menciptakan ketergantungan-ketergantungan baru kepada berbagai pihak. 
f. Dalam prakteknya, sebagai salah satu teknik yang berguna perlu dikembangkan kegiatan diskusi dalam bentuk kelompok yang bisa saling mengkritisi permasalahan yang dihadapi.

g. Perlu penguatan organisasi kelembagaan petani yang makin baik dalam menetapkan arah pembangunan di kawasan agropolitan

h. Perlu diciptakan institusi/lembaga di tingkat lapangan agar upaya pengembangan kawasan dapat terkoordinasi dengan baik.

i. Khusus Kabupaten Kampar perlu dilakukan sosialisasi agar berbagai pihak yang terkait dapat memberikan dukungan yang akan menghasilkan sinergi kegiatan demi kesejahteraan masyarakat.

\section{DAFTAR PUSTAKA}

1. BAPPEDA Kabupaten Cianjur, Model Pengembangan Agropolitan, Kecamatan Sukaresmi dan Cugenang, Cianjur, 2004.

2. CV. Median Konsultant, Pelaksanaan Pekerjaan Detail Engineering Design (DED) Kawasan Agropolitan, Lokasi Kualu Nenas, Kelurahan Pulau, dan Sekijang.

3. CV. Putra Muslim Perkasa, Final Report Penyusunan Master Plan Kawasan Agropolitan Kecamatan Tempuling Kabupaten Inhil, Riau, Departemen Kimpraswil, Dirjend Tata Kota dan Pedesaan, Bagian Proyek Pengembangan Prasarana dan Sarana Desa Agropolitan (P2SD-AGRO) Propinsi Riau, 2003.

4. CV. Tazakki Enginering, Penyusunan Rencana Pengembangan Jangka Menengah Kawasan Agropolitan Kampar.

5. Departemen Pertanian, Pedoman Umum Pengembangan Kawasan Agropolitan dan Pedoman Rintisan Pengembangan Kawasan Agropolitan, Badan Pengembangan SDM Pertanian Jakarta, 2002

6. Departemen Pertanian, Pedoman Operasional Pengembangan Kawasan Agropolitan, Badan Pengembangan SDM Pertanian Jakarta, 2002 
7. Pusat Pengembangan Kewirausahaan Agribisnis, Profil Kawasan Agropolitan, Badan Pengembangan SDM Pertanian, Departemen Pertanian, Jakarta, 2004.

8. Pemerintah Propinsi Riau, Peluang Investasi dan Komoditas Unggulan Propinsi Riau, Sekretariat Propinsi, Pekanbaru, 2001.

9. PT. Kesta Indah Prima, Laporan Akhir Penunjang Penyusunan Master Plan Kawasan Agropolitan Kab. Inhil, Dinas Pertanian Tanaman Pangan dan Hortikultura Kab. Inhil, 2003.

10. Suwandi, H.,Ir, MM, Agropolitan, Merentas Jalan Meniti Harapan, PT Duta Karya Swasta, Jakarta, 2005. 